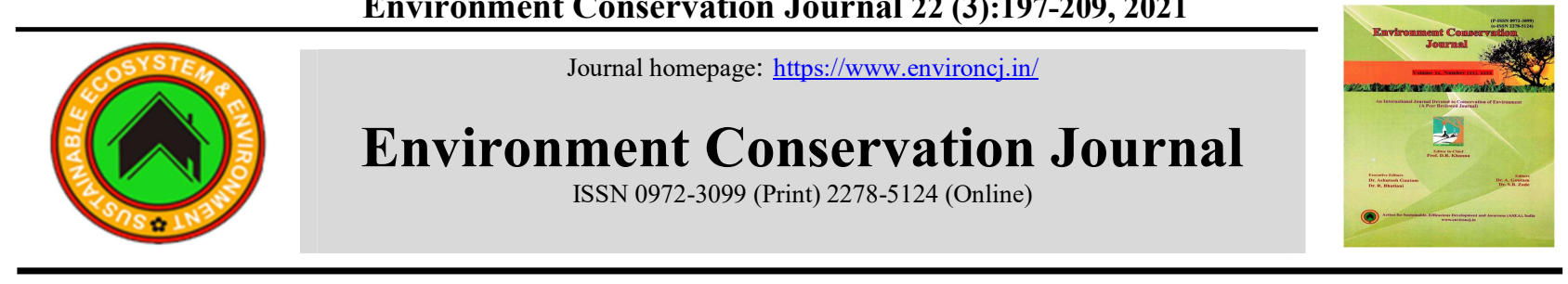

\title{
Friendly microbes help rice to grow and suppress its pathogens: Trichoderma and Bacillus Vs Xanthomonas in rice
}

\author{
Divya Mishra 四 \\ Jayashankar Telangana State Agricultural University \\ Rajeswari B. \\ Jayashankar Telangana State Agricultural University \\ P. Raghuveer Rao \\ ICAR- Indian Institute of Rice Research, Hyderabad, Telangana \\ T. Uma Maheswari \\ Jayashankar Telangana State Agricultural University \\ Kannan C. \\ ICAR- Indian Institute of Rice Research, Hyderabad, Telangana
}

\begin{tabular}{|c|c|}
\hline ARTICLE INFO & ABSTRACT \\
\hline $\begin{array}{l}\text { Received : } 10 \text { June } 2021 \\
\text { Revised : } 08 \text { August } 2021 \\
\text { Accepted : } 11 \text { August } 2021\end{array}$ & $\begin{array}{l}\text { Use of biological control for the management of diseases has gained huge } \\
\text { awareness and importance in the present situation of climate change and food } \\
\text { residues. Biocontrol agents play interesting role in developing plant health and } \\
\text { provide protection against biotic and abiotic stresses. In this study, we isolated }\end{array}$ \\
\hline Available online:9 December 2021 & $\begin{array}{l}\text { Trichoderma and Bacillus sp. isolated from soil samples collected from rice } \\
\text { fields in Kharif } 2019 \text {. Profiling based on the } \mathrm{pH} \text { of the soil, the fungal bioagents }\end{array}$ \\
\hline Key Words: & were more present in slightly acidic to neutral $\mathrm{pH}(5.8-7.2)$ whereas bacterial \\
\hline Biocontrol & bioagents in slightly neutral to basic (7.4-8.3). The isolates were screened for \\
\hline Rice & their ability to produce phytohormones, cell-wall degrading enzyme and \\
\hline Trichoderma & biofilm. Based on biochemical screening two Trichoderma isolates (T6 and T7) \\
\hline Bacillus & and two Bacillus isolates (B1 and B5) were subjected to glasshouse studies. Per \\
\hline Xanthomonas & cent diseased leaf area and lesion length of plants treated with $B 1$ were found to \\
\hline Oryzae pv. oryzae & $\begin{array}{l}\text { be effective against pathogen. However, the plant growth promotion was more } \\
\text { enhanced by T6. Scanning electron microscopy and molecular characterisation } \\
\text { along with their phylogenetic analysis proved the identity of isolate B1 as } \\
\text { Bacillus subtilis and T6 as Trichoderma atroviride. }\end{array}$ \\
\hline
\end{tabular}

\section{Introduction}

Biological control in sustainable agriculture is providing promising contributions to manage the diseases and promote growth of the crop plants (O'Brien, 2017). It is the major element in integrated disease/pest management programme in agriculture in many countries (Ram et al., 2018) and because of its stability and longevity, it is now considered as the primary method for disease/pest control. Biocontrol agents viz., Trichoderma, Bacillus, Pseudomonas, Streptomyces etc. are being utilized in agriculture and industrial sectors on large scale (O'Brien, 2017). They are used in production of biofertilizers, biopesticides and phytostimulators. They have excellent capacity to release growth

promoting hormones which helps in the healthy development of plants (Doni et al., 2014). They also possess strong antagonistic activities against various plant pathogens in different environmental conditions through direct mechanisms like hyperparasitism, antibiosis, competition of nutrients etc. and indirect mechanisms like systemic acquired resistance (SAR) and induced systemic resistance (ISR) (Pieterse et al., 2014; Singh et al., 2019).

Rice being one of the most important food crops for more than half of the world's population, is continuously attacked by various biotic and abiotic stresses that leads to immense loss to crop (Hastuti et al., 2012). Due to change in climate, genotypes 
grown and cultivation practices, the profile of the diseases in rice has changed over a period of time. Among the bacterial diseases, bacterial blight caused by Xanthomonas oryzae pv. oryzae (Xoo) has caused tremendous yield loss to the farmers (Brunner et al., 2005). Spraying of antibiotics is causing harmful residual effect on the soil. Though resistant varieties have gained popularity, but sudden breakdown of the resistance gene cause huge loss to the yield and income to the farmers. In order to complement the existing management strategies, biocontrol gives safe, sustainable and viable solution to the farmers to control the disease (Marin et al., 2019).

The current experiment was conducted to isolate beneficial microbes from rice rhizosphere soil of Telangana state and study its characteristics to be a potential biocontrol agent against Xoo. The Trichoderma and Bacillus isolates were screened for their IAA, phosphate solubilisation, siderophore, cell-wall degrading enzymes and biofilm production capacity. They were tested for in-vitro for their capacity to inhibit growth of Xoo and on the basis of this results, potential bioagents were tested for their efficacy against Xoo under glasshouse conditions. The best fungal and bacterial isolates from in-vivo results were identified and the DNA sequence were submitted to NCBI.

\section{Material and Methods}

Soil samples were collected from different rice growing regions of Telangana state (Table 1) to isolate fungal and bacterial bioagents during Kharif
2019 (hot and humid climate: RH: 80\%). At two vertical depths $-15 \mathrm{~cm}$ and $30 \mathrm{~cm}$; the soil samples were taken randomly from field with the help of post- hole auger, air dried and taken for serial dilution. The $\mathrm{pH}$ of soil samples were recorded. Stock solution for all the samples were prepare by dissolving $1 \mathrm{~g}$ of soil in $9 \mathrm{ml}$ of water. Samples were then diluted and fungal bioagents were isolated from dilution factor $10^{-4}$ by evenly spreading one $\mathrm{ml}$ of prepared dilution on Trichoderma specific medium (TSM). For bacterial bioagents (Bacillus sp.), stock soil sample were heated at $65^{\circ} \mathrm{C}$ for $5 \mathrm{~min}$ and then were isolated same as above in Luria Bertani agar (LBA) medium from dilution factor $10^{-8}$. The plates were then incubated at $25 \pm 2^{\circ} \mathrm{C}$ for 7 days for fungal and 2 days for bacterial bioagents. Morphological identification of fungal and bacterial bioagents were done based on colony structure in specific media (Istock, 2008; Gupta et al., 2014). Microscopic identification of fungal bioagents were done by staining the sample with methylene blue and observing at $40 \mathrm{X}$ magnification in compound microscope. For bacterial bioagents, Gram staining was done and observed at $100 \mathrm{X}$ magnification in compound microscope. Fungal isolates were tested for their growth promoting activities by quantitative estimation of Indole acetic acid (IAA) (Gravel et al., 2007), Phosphate solubilisation (Saravanakumar et al., 2013), siderophore production (Payne, 1994), chitinase production (Miller, 1959) and $\beta-1,3$-gucanases (Ramada et al., 2010) in-vitro.

Table 1: Rice rhizosphere samples from different locations of Telangana state

\begin{tabular}{|l|l|l|l|l|l|l|l|}
\hline District & Mandal & $\begin{array}{l}\text { Collection } \\
\text { date }\end{array}$ & Soil type & $\begin{array}{l}\text { Cropping } \\
\text { pattern }\end{array}$ & Rice variety & Latitude & Longitude \\
\hline Hyderabad & Rajendranagar & $22-8-19$ & $\begin{array}{l}\text { Black } \\
\text { cotton soil }\end{array}$ & Rice-Rice & $\begin{array}{l}\text { Samba Mahsuri } \\
\text { (BPT-5204) }\end{array}$ & $\begin{array}{l}17.3220^{\circ} \\
\mathrm{N}\end{array}$ & $78.4023^{\circ} \mathrm{E}$ \\
\hline Khammam & Wyra & $12-9-19$ & Red soil & $\begin{array}{l}\text { Rice- } \\
\text { Chilli }\end{array}$ & $\begin{array}{l}\text { Telangana Sona } \\
\text { (RNR-15048) }\end{array}$ & $\begin{array}{l}17.2473^{\circ} \\
\mathrm{N}\end{array}$ & $8^{\circ} .1514^{\circ} \mathrm{E}$ \\
\hline Khammam & Mittapalli & $12-9-19$ & Red soil & $\begin{array}{l}\text { Rice- } \\
\text { Maize }\end{array}$ & $\begin{array}{l}\text { Telangana Sona } \\
\text { (RNR-15048) }\end{array}$ & $\begin{array}{l}17.2473^{\circ} \\
\mathrm{N}\end{array}$ & $80.1514^{\circ} \mathrm{E}$ \\
\hline Nalgonda & Chandupatla & $19-9-19$ & Red soil & Rice-Rice & $\begin{array}{l}\text { Samba Mahsuri } \\
\text { (BPT-5204) }\end{array}$ & $\begin{array}{l}17.1883^{\circ} \\
\mathrm{N}\end{array}$ & $7_{79.2000^{\circ} \mathrm{E}}$ \\
\hline Nalgonda & Katangur & $19-9-19$ & $\begin{array}{l}\text { Black } \\
\text { cotton soil }\end{array}$ & $\begin{array}{l}\text { Rice-Rice } \\
\text { Samba Mahsuri } \\
\text { (BPT-5204) }\end{array}$ & $\begin{array}{l}17.1883^{\circ} \\
\mathrm{N}\end{array}$ & $79.2000^{\circ} \mathrm{E}$ \\
\hline Nalgonda & Inupamula & $19-9-19$ & Red soil & $\begin{array}{l}\text { Rice- } \\
\text { Maize }\end{array}$ & $\begin{array}{l}\text { Telangana Sona } \\
\text { (RNR-15048) }\end{array}$ & $\begin{array}{l}17.1883^{\circ} \\
\mathrm{N}\end{array}$ & $79.2000^{\circ} \mathrm{E}$ \\
\hline Suryapet & Husainabad & $25-9-19$ & Red soil & $\begin{array}{l}\text { Rice- } \\
\text { Horse } \\
\text { gram }\end{array}$ & $\begin{array}{l}\text { Telangana Sona } \\
\text { (RNR-15048) }\end{array}$ & $\begin{array}{l}17.1314^{\circ} \\
\mathrm{N}\end{array}$ & $79.6336^{\circ} \mathrm{E}$ \\
\hline
\end{tabular}


Quantitative estimation of growth promoting parameters of bacterial bioagents included Indole acetic acid (IAA) (Brick et al.,1991), Phosphate solubilisation (Nautiyal, 1999), siderophore production (Schwyn and Neilands, 1987) and biofilm production (Yousef et al., 2008) in-vitro. The pathogen was isolated from diseased leaf samples showing peculiar symptom of bacterial blight, collected from rice growing areas in Rajendranagar, Hyderabad. The diseased portion with healthy tissues was cut into 1.5 to $2 \mathrm{~cm}$ pieces and surface sterilized with 0.1 per cent sodium hypochlorite solution. These leaf pieces were further cut on microscopic slide with sterilized blade and upon that sterilized distilled water was dropped for preparation of bacterial suspension. This suspension was streaked on modified Wakimoto's agar (MWA) medium with the help of sterilized wire loop. The inoculated plates were incubated at room temperature $\left(27 \pm 2^{\circ} \mathrm{C}\right)$ for 48 hrs. The identification of Xoo was done with cultural morphology, gram staining, and 16s rRNA sequence analysis. Dual culture assay was performed in order to test the efficiency of isolated bioagents and pathogen. Ten Trichoderma and five Bacillus isolates were used for evaluating the suppression potential against Xoo. The media for dual culture was MWA as it allows both the bioagents to grow perfectly as it does for Xoo. Five $\mathrm{mm}$ bit from pure cultures of Trichoderma isolates were kept at one edge and Xoo at another edge in the petriplate maintaining equal distance from the centre. Control was maintained with only Xoo isolate. The radial growth of Xoo was measured in treated and control plate by the formula (Gangwar and Sinha, 2010)

Per cent inhibition $(\%)=\frac{\mathrm{C}-\mathrm{T}}{\mathrm{C}} \times 100$

Where, $\mathrm{C}=$ Colony growth in centimetre in control plate, $\mathrm{T}=$ Colony growth in centimetre in treated plate

For testing the antagonism efficiency of Bacillus isolates, the cultures were grown on Luria Bertani broth (LB) for $48 \mathrm{hrs}$ and then the cultural filtrate (supernatant) was collected by centrifugation at $10000 \mathrm{rpm}$ for 6 mins. The filtrate was passed through bacterial filter $(0.22 \mu \mathrm{m}) 2$ times so that no bacterial cells will remain in filtrate. This filtrate was then diluted by LB to make different concentrate $(20,40,60,80$ and $100 \%)$ and tested against $X o o$ to find out minimum inhibitory concentration. Filter paper disc of $0.5 \mathrm{~cm}$ radius were sterilised and dipped in different concentration of each bacterial isolate's filtrates. In the plate, first Xoo was streaked and then filter paper containing filtrate was placed at four places in the plate. Controls were maintained separately with no filtrate. Antibacterial activity was analysed by measuring the mean zone of inhibition diameters formed by individual filtrates (Balouiri et al., 2016). Waste rice grains with husk were taken for mass multiplication of bioagents. The grains were coarsely grinded in mixer grinder kept in trays for bioagent application. Bioagents were grown in selective broth viz., Potato dextrose broth (PDB) and LB for Trichoderma and Bacillus isolates respectively. For Trichoderma isolates, the fullgrown fungal mat with spores was separated with sterile forceps and crushed in mortar pestle to make slurry. This paste was poured in trays maintaining CFU@2.14 x 10 $10^{6} / \mathrm{ml}$ and moisture content of $68.23 \pm 0.07 \%$. In case of Bacillus isolates, the culture in LB was shacked completely and poured in trays with CFU of $1.08 \times 10^{8} / \mathrm{ml}$ and moisture content of $70.35 \pm 0.02 \%$. The mixtures were used for soil application @ $10 \mathrm{~g} / \mathrm{Kg}$ of soil. Rice susceptible cultivar Taichung native 1 (TN1) was taken for in-vivo evaluation of all the isolated bioagents against Xoo. Potential Trichoderma isolate's spores and Bacillus isolate's culture (selected based on in-vitro studies) were harvested with the help of autoclaved water and the obtained suspension optical density $\left(\mathrm{OD}_{600 \mathrm{~nm}}\right)$ was maintained for 1.0 and 0.4 respectively. The seeds were first soaked in water for 12 hours and then with all the bioagent's suspension for 12 hours. Twenty-five days after sowing, the seedlings were dipped in each bioagents solution containing $2 \%$ carboxymethyl cellulose (CMC) in separate beakers for 6 hours. These seedlings were then transplanted into pots of size $30 \times 25 \mathrm{~cm}$ maintaining $5 \mathrm{~kg}$ of soil. After 30days of transplanting, the soil was again treated with bioagents @ $50 \mathrm{~g} /$ pot. Suspension of Xoo culture was prepared $\left(\mathrm{OD}_{600 \mathrm{~nm}}=0.4\right)$ from freshly grown culture and was inoculated by clipinoculation method on $40^{\text {th }}$ day after transplanting (DAT). Disease screening was done at two intervals $14^{\text {th }}$ day after inoculation (DAI) and $21^{\text {st }}$ DAI. Data for plant growth promotion activities were recorded 
upto maturity. From in-vivo results analysis, the potential bioagent isolates and pathogen were taken for scanning electron microscopy to know their detailed structure. The preparation of samples was done by following the procedure given by Bozzola and Russell (1999). The fresh samples were fixed in $2 \%$ glutaraldehyde prepared with $0.1 \mathrm{M}$ phosphate buffer ( $\mathrm{pH} 7.2)$ for a day at $4^{\circ} \mathrm{C}$. The samples were again subjected to $2 \%$ aqueous osmium tetroxide for $4 \mathrm{~h}$ followed by dehydration with alcohol and EMS $850 \mathrm{CP}$ dryer. Using automated sputter coater (Model- JEOL JFC-1600) the samples were mounted with double sided carbon conductivity tape and a thin layer of gold coat for 2 minutes. JEOL JSM-5600 SEM was used for observation of samples. The potential isolates of fungal and bacterial bioagents were taken for genomic DNA isolation, 18s rRNA (ITS region) and 16s rRNA sequence analysis, nucleotide sequencing and NCBI submission respectively. The freshly grown culture's cells (Log phase) of bacterial isolates in LB and fungal isolates in PDB were harvested and collected by centrifugation at $11,000 \mathrm{rpm}$ for $10 \mathrm{mins}$ and taken for DNA isolation and purification using MN (Machery-Nagel) kit. The quantification of DNA was done using agarose gel electrophoresis $(0.8 \%)$ as well as Nanodrop. For bacterial DNA, 16S rRNA region $(\sim 1500 \mathrm{bp})$ was amplified by using universal primer $27 \mathrm{~F}$ (5'AGAGTTTGATCMTGGCTCAG-3') and reverse primer 1492R (5'-CGGTTACCTTGTTACGACTT3 '). The PCR was performed by preparing master mixture with 50ng DNA template, $0.5 \mu \mathrm{M}$ primers, 2.5mM dNTP mix, $10 \mathrm{mM}$ Tris- $\mathrm{HCl}(\mathrm{pH} 8.3), 1.5$ $\mathrm{mM} \mathrm{MgCl}_{2}, 5 \mathrm{U}$ Taq polymerase. Amplification was done by running $5 \mathrm{~min}$ denaturation at $94^{\circ} \mathrm{C}$ followed by 30cycles of amplification with denaturation at $94^{\circ} \mathrm{C}$ for $30 \mathrm{~s}$, annealing at $60^{\circ} \mathrm{C}$ for $20 \mathrm{~s}$, extension at $74^{\circ} \mathrm{C}$ for $45 \mathrm{~s}$ and final extension at $74^{\circ} \mathrm{C}$ for $7 \mathrm{~min}$. For fungal DNA, $18 \mathrm{~S}$ rRNA gene ( 1200bp) (partial sequence); internal transcribed spacer 1, 5.8S rRNA gene, and internal transcribed spacer 2 (complete sequence); and 28S rRNA gene (partial sequence) was amplified using ITS1 (5'TCCGTAGGTGAACCTGCGG-3') and LR3R (5'GGTCCGTGTTTCAAGAC-3') primers. The amplification was done by running 30 cycles of denaturation at $94^{\circ} \mathrm{C}$ for $1 \mathrm{~min}$, annealing at $50^{\circ} \mathrm{C}$ for $90 \mathrm{sec}$ followed by one more annealing at $72^{\circ} \mathrm{C}$ for $90 \mathrm{sec}$, extension at $74^{\circ} \mathrm{C}$ for $45 \mathrm{~s}$ and final extension at $74^{\circ} \mathrm{C}$ for $10 \mathrm{~min}$.

PCR product was analysed on 1\% agarose gel containing ethidium bromide and visualised under UV transilluminator. Desired band from PCR product was purified using QIAGEN gel extraction kit. Sanger sequencing was done at Eurofins Genomics, India. NCBI BLAST system was used for nucleotide homology analysis for $16 \mathrm{~S}$ and $18 \mathrm{~S}$ region for bacteria and fungi respectively. For analysis of evolutionary pattern among closest lineages, phylogenetic tree was constructed by acquiring the sequence database of our isolates and homologous nucleotide sequences from NCBI, aligning them in one FASTA format file and designing the tree in MEGA software. On the basis of more than $90 \%$ similarity sequence with the tested sequences, database was collected and aligned for making phylogenetic tree using ClustalX version 2.0.11 and MEGA version 6.06. Studies at in-vitro level was performed twice with three replications. The experiment at glasshouse level was conducted for four replications in completely randomised design (CRD). One-way analysis of variance (ANOVA) having Post hoc test with Duncan's multiple range test (DMRT) at 5\% $(P \leq 0.05)$ significance level was performed in SPSS 20.0 software. Regression analysis and graphs designing were done in Microsoft Excel (2019).

\section{Results and Discussion}

From seven different places of four rice growing districts of Telangana viz., Hyderabad, Khammam, Nalgonda and Suryapet, 10 isolates of Trichoderma and 5 isolates of Bacillus were isolated. The major soil type found was black cotton soil and red soil. The fungal isolates were mainly found in red soils with the $\mathrm{pH}$ range of 5.8-7.2 and the bacterial isolates in black cotton soil with a $\mathrm{pH}$ range of 7.48.3 (Figure 1). Telangana state is situated in upland region of Deccan (peninsular India) plateau which is covered with gneissic rock. As a result of erosion, the topography of the region consists of majorly red sandy soil and black soil in certain parts of the area. These soil type have different $\mathrm{pH}$ range which nurture various microbial diversity in soil (Mahesh et al., 2018). On the basis of morphological and microscopic features, fungal and bacterial bioagents were identified (Table 2 and 3). 
Table 2: Morphological characterisation of isolated fungal bioagents

\begin{tabular}{|c|c|c|c|c|c|}
\hline Isolates & $\begin{array}{l}\text { Radial growth (cm) in } \\
\text { TSM after } 4 \text { days of } \\
\text { incubation }\end{array}$ & $\begin{array}{l}\text { Colony structure and colour of spores after } 4 \text { days of } \\
\text { incubation }\end{array}$ & $\begin{array}{l}\text { Spore } \\
\text { maturation } \\
\text { period }\end{array}$ & Chlamydospore & Conidiospores \\
\hline T1 & $3.0 \pm 0.02$ & Thin mat of mycelium with dispersed dark green spores & 5 & Absent & Rarely branched \\
\hline $\mathrm{T} 2$ & $3.1 \pm 0.01$ & Thick mat of mycelium with dispersed dull green spores & 6 & Absent & Broad and verticillate \\
\hline $\mathrm{T} 3$ & $3.6 \pm 0.05$ & $\begin{array}{l}\text { Thick mat of mycelium with dark green spores clustered } \\
\text { in ring }\end{array}$ & 4 & Present & Branched, pyramidal structure \\
\hline $\mathrm{T} 4$ & $2.0 \pm 0.01$ & Thick fluffy mat of mycelium light green spores & 3 & Present & Infrequently branched \\
\hline T5 & $3.8 \pm 0.01$ & Thin mat of mycelium with light green spores & 4 & Absent & $\begin{array}{l}\text { Divergently branched at right } \\
\text { angle }\end{array}$ \\
\hline T6 & $4.5 \pm 0.02$ & Thin mat of mycelium with clustered light green spores & 2 & Present & Branched, bottle shaped phiallids \\
\hline $\mathrm{T} 7$ & $4.3 \pm 0.00$ & Thick mat of mycelium with dark green spores & 2 & Present & $\begin{array}{l}\text { Long and infrequently branched, } \\
\text { verticillate }\end{array}$ \\
\hline $\mathrm{T} 8$ & $3.0 \pm 0.01$ & Thin mat of mycelium with yellowish green spores & 5 & Absent & $\begin{array}{l}\text { Divergently branched at right } \\
\text { angle }\end{array}$ \\
\hline T9 & $3.4 \pm 0.05$ & Thin mat of mycelium with dull green tufts of spores & 8 & Absent & Clustered, verticillate \\
\hline $\mathrm{T} 10$ & $3.9 \pm 0.03$ & Thin mat of mycelium with dispersed green spores & 4 & Absent & $\begin{array}{l}\text { Divergently branched at right } \\
\text { angle }\end{array}$ \\
\hline
\end{tabular}

Note: Data depicts the mean of three replications

Table 3: Morphological characterisation of isolated bacterial bioagents

\begin{tabular}{|l|l|l|l|l|}
\hline Isolates & $\begin{array}{l}\text { Growth of culture } \\
\text { (hours) }\end{array}$ & Colony configuration & $\begin{array}{l}\text { Colour on nutrient } \\
\text { agar }\end{array}$ & Shape of isolates \\
\hline B1 & $18 \pm 0.50$ & Circular lobate with irregular margin and flat & White & Ellipsoidal \\
\hline B2 & $36 \pm 0.38$ & Circular, slightly granular but not dry & Dull grey \\
\hline B3 & $24 \pm 0.58$ & Flat or slightly convex, irregular & Off-white & Ellipsoidal \\
\hline B4 & $30 \pm 0.65$ & Oval, opaque, dry & Off-white & Oval \\
\hline B5 & $21 \pm 0.57$ & Round, smooth, moist & Rod \\
\hline
\end{tabular}

Note: Data depicts the mean of three replications 
Figure 1: Distribution of species in the soil samples at different $\mathrm{pH}$

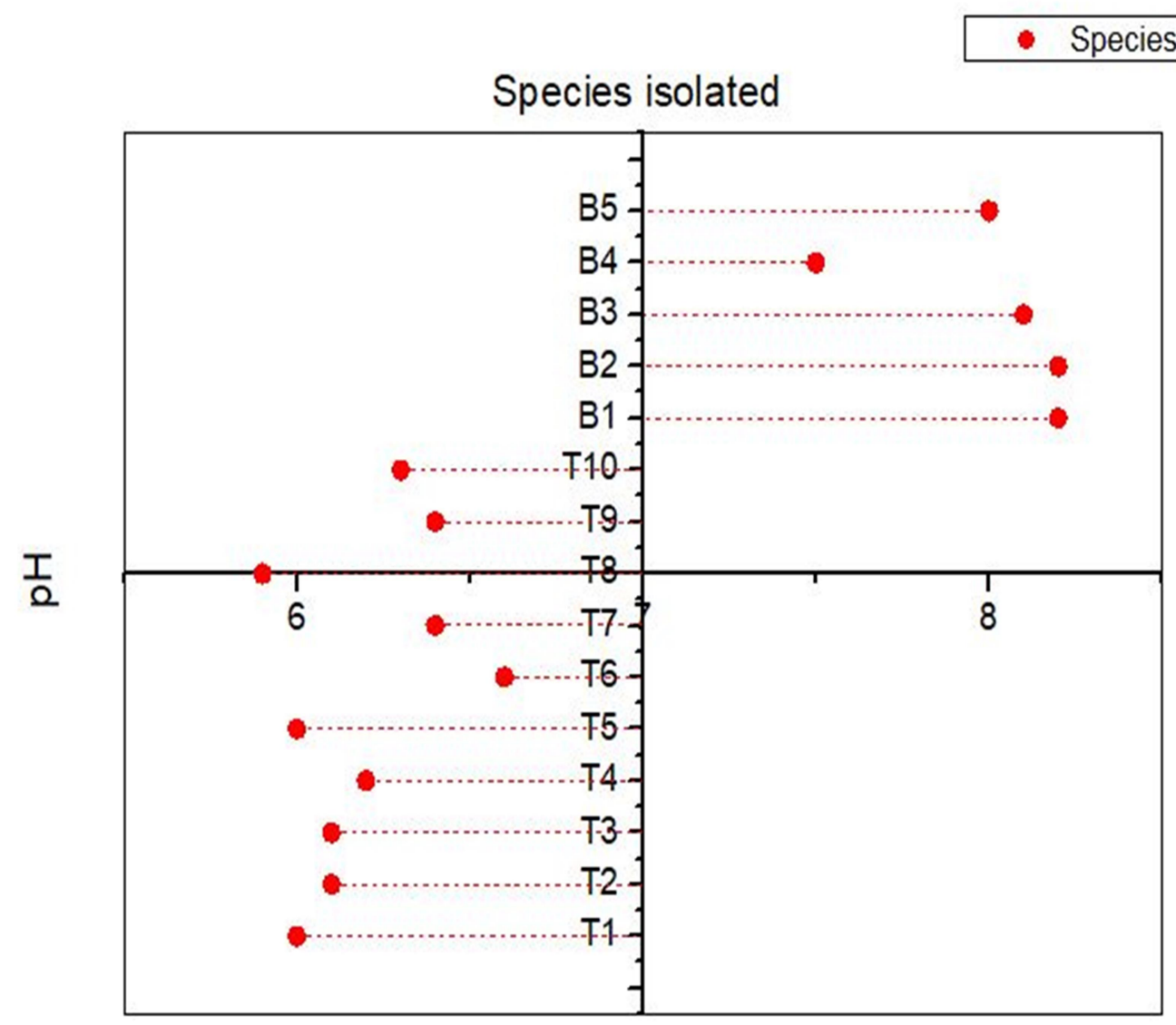

Note: The soil samples collected from different regions of Telangana were tested for its pH content. X-axis represents the pH range and Y-axis represents different bioagents isolated.

Fungal bioagent identified as Trichoderma atroviride and bacterial bioagent Bacillus subtilis are generally cosmopolitan and free-living organism which are commonly found in soil. This nature makes them an ideal candidate in biocontrol programmes against a range of phytopathogenic fungi or bacteria in different environmental habitats (Reithner et al., 2011; Ashwini and Srividya, 2014). They maintain symbiotic relationship with plants and act as potential decomposers. They colonise the root surface or lives endophytically and helps to increase plant growth. As decomposers, they make nutrients as well as play significant role in nitrogen and carbon cycle for plant development (Lieckfeldt et al., 1999). Among the fungal bioagents, T6 isolate was showing highest production of IAA $(69.73 \mathrm{mg} / \mathrm{ml})$, PS $(153.16 \mu \mathrm{g} / \mathrm{ml})$, siderophores (92.70 \%siderophore units), chitinases (32.52 $\mathrm{min}^{-1}$ $\mathrm{mg}^{-1}$ Protein) and $\beta-1,3$-gucanases $(1.93 \mathrm{nmol} / \mathrm{s} / \mathrm{ml})$ (Figure 2) (Supplementary Table 1). Among bacterial bioagents, B1 isolate was showing maximum production of IAA $(10.97 \mathrm{mg} / \mathrm{ml})$, PS $(65.87 \mu \mathrm{g} / \mathrm{ml})$, siderophores $(40.35 \%$ siderophore units) and biofilm (1.48 $\left.\mathrm{OD}_{600 \mathrm{~mm}}\right)$ (Figure 3) (Supplementary Table 2). Plant growth promoting and antagonistic activities of the bioagents on rice plants has been attributed with the production of indole acetic acid, phosphate solubilisation, siderophore, chitinase, $\beta$-1,3-gucanases and biofilm. The phytohormone IAA helps in the enhancement of root and shoot length of the plant (Naziya et al., 2020; Chinnaswami et al., 2021). The ability to hydrolyse organic and inorganic insoluble phosphorus compounds to soluble P helps plants to take up phosphorus easily and utilise for further developmental processes (Prakash and 
Table 4: Evaluation of antagonistic activity of fungal bioagents against $X o o$.

\begin{tabular}{|l|l|l|}
\hline Isolate & $\begin{array}{l}\text { Radial growth of } \\
\text { Xoo (96 hrs of } \\
\text { incubation) }\end{array}$ & $\begin{array}{l}\text { Percent } \\
\text { inhibition }\end{array}$ \\
\hline T1 & $0.52 \pm 0.50$ & 54 \\
\hline T2 & $0.76 \pm 0.33$ & 36 \\
\hline T3 & $0.61 \pm 0.50$ & 45 \\
\hline T4 & $0.49 \pm 0.96$ & 63 \\
\hline T5 & $0.51 \pm 0.20$ & 54 \\
\hline T6 & $\mathbf{0 . 2 0} \pm 0.58$ & $\mathbf{8 1}$ \\
\hline T7 & $\mathbf{0 . 3 5} \pm 0.65$ & $\mathbf{7 2}$ \\
\hline T8 & $0.51 \pm 0.30$ & 54 \\
\hline T9 & $0.72 \pm 0.43$ & 36 \\
\hline T10 & $0.58 \pm 0.33$ & 54 \\
\hline Control & $1.10 \pm 0.74$ & - \\
\hline
\end{tabular}

Note: Data represents the mean of three replications with standard error values

Table 5: Evaluation of antagonistic activity of bacterial bioagents against $X o o$

\begin{tabular}{|l|l|}
\hline Isolates & Zone of inhibition (cm) \\
\hline B1 & $2.46 \pm 0.31$ \\
\hline B2 & $1.33 \pm 0.50$ \\
\hline B3 & $1.80 \pm 0.24$ \\
\hline B4 & $1.59 \pm 0.82$ \\
\hline B5 & $2.01 \pm 0.12$ \\
\hline Control & - \\
\hline
\end{tabular}

Note: Data represents the mean of three replications with standard error values
Arora, 2019). The high affinity system to uptake iron from the environment by plants with the help of these bioagents may enhance plant growth promoting activity (Scavino and Pedraza, 2013). The cell-wall degrading enzymes (chitinase and $\beta$ 1,3-gucanases) and production of biofilm helps the plants to induce resistance and kill the pathogen (Naziya et al., 2020). Typical pin head size, mucoid, convex yellow colonies were identified as Xoo and was streaked on MWA plates. Pathogenicity of the isolate was proved on rice susceptible cultivar: TN1 and the growth of pathogen was measured and compared on the basis of standard evaluation system (SES) scale. The per cent leaf area diseased was found to be more that $70 \%$ after 21 days of Xoo inoculation. Based on reduction in the radial growth of Xoo, the per cent inhibition of pathogen by T6 $(81 \%)$ was highest followed by T7 (72\%) (Table 4). In case of Bacillus culture filtrate, each isolate was successfully able to reduce the growth of Xoo. The lethal concentration for each isolate was optimised to $60 \%(\mathrm{v} / \mathrm{v})$. Clear zone of inhibition was found after $72 \mathrm{hrs}$ of incubation and was highest in B1 $(2.46 \pm 0.31 \mathrm{~cm})$ when compared with other isolates (Table 5). Their antagonistic capacity has made their importance to be recognised in production of biopesticides, biofertilizers and phytostimulants (Kumar and Singh, 2015).

Figure 2: Stacked bar representation of different biochemical characters of Trichoderma isolates

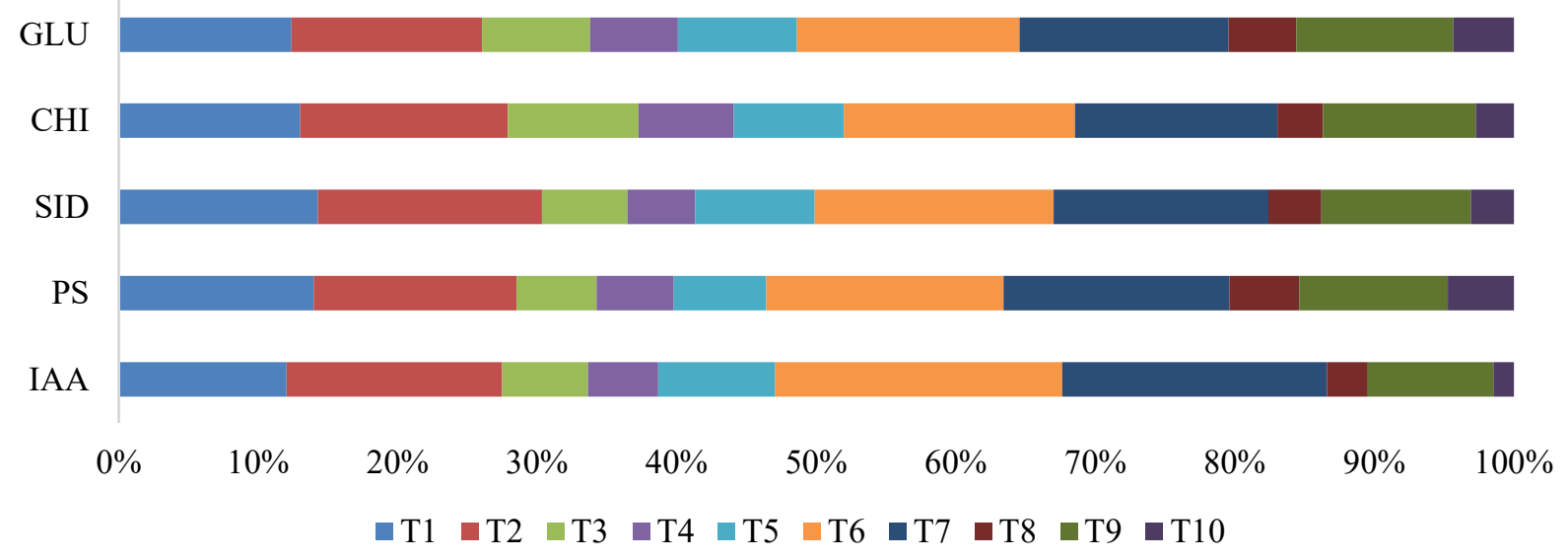

Note: Data depicts the mean of three replications. Stacked bar $(\mathbf{1 0 0 \% )}$ represents percentage of the whole of each group and are plotted by the percentage of each value of the total amount in each group. GLU: Glucanase, CHI: Chitinase, SID: Siderophore, PS: Phosphate solubilisation and IAA: Indole acetic acid 
Figure 3: Stacked bar representation of different biochemical characters of Bacillus isolates.

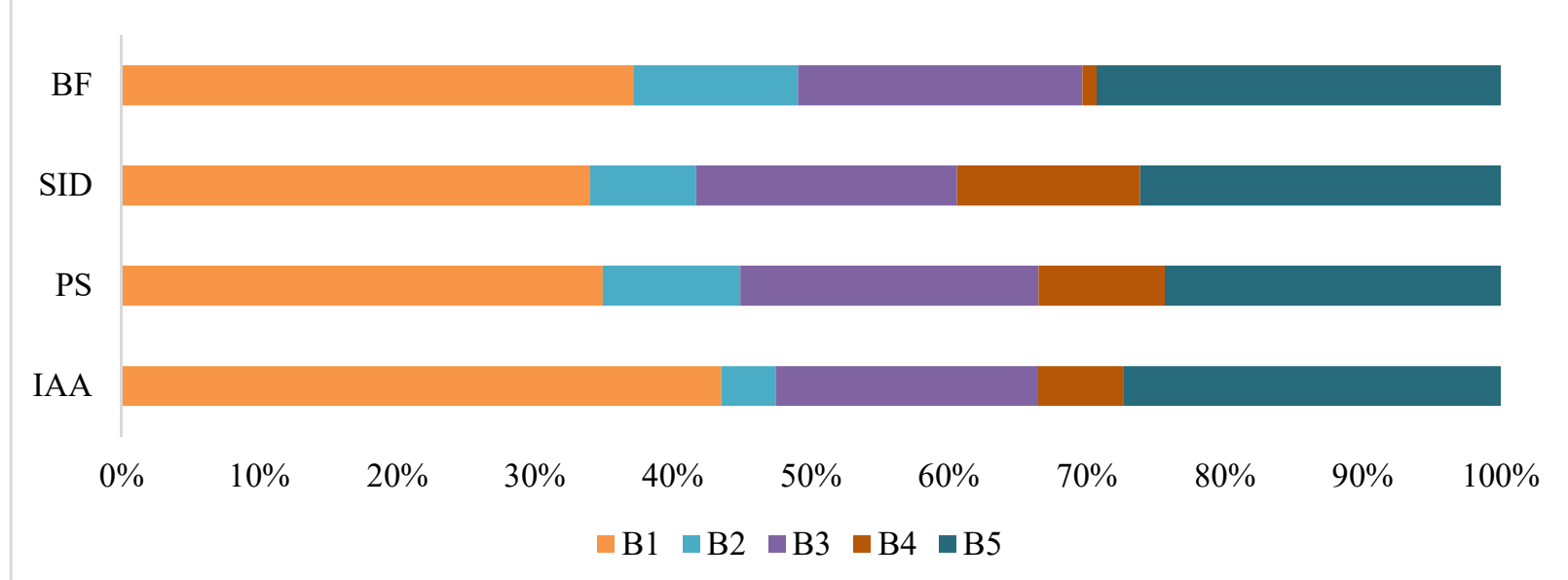

Note: Data depicts the mean of three replications. Stacked bar $(\mathbf{1 0 0 \%})$ represents percentage of the whole of each group and are plotted by the percentage of each value of the total amount in each group. BF: Biofilm, SID: Siderophore, PS: Phosphate solubilisation and IAA: Indole acetic acid

Figure 4: Stacked bar representation of morphological and yield parameters of rice plants in different treatments under glasshouse conditions.

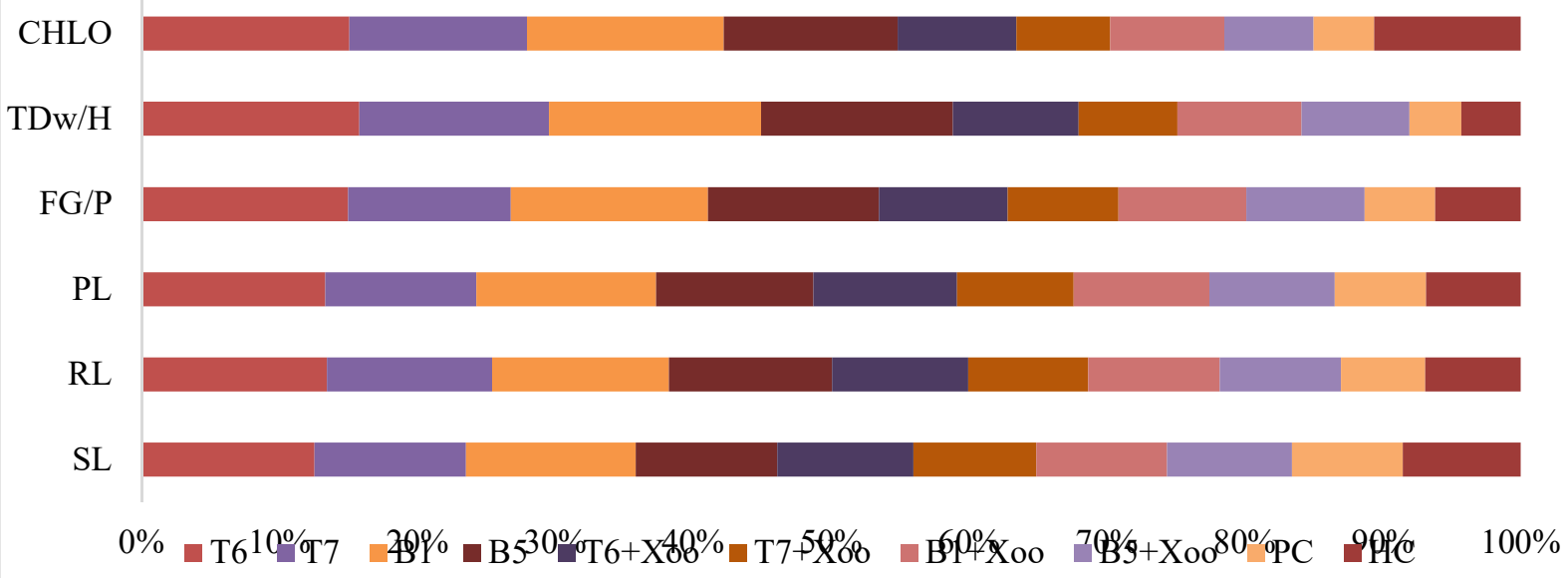

Note: Data depicts the mean of three replications. Stacked bar $(\mathbf{1 0 0 \% )}$ represents percentage of the whole of each group and are plotted by the percentage of each value of the total amount in each group. CHLO: Chlorophyll, TDw/H: Total dry weight/hill, FG/P: Filled grains per panicle, PL: Panicle length, RL: Root length, SL: Shoot length, PC: Pathogen control and HC: Healthy control

The in-vitro growth inhibition of Xoo by results, two potential Trichoderma (T6 and T7) and Trichoderma species was may be due to Bacillus (B1 and B5) isolates were taken for in-vivo competition of nutrients which reduces the growth study. In comparison with positive and negative and biofilm production of Xoo. The saprophytic control plants, rice plants treated with bioagents ability of Trichoderma sp. might be the reason for showed better growth promotion activities and the overgrowth of bioagents on the pathogen reduced spread of Xoo in the infected leaves. (Mukherjee et al., 2013). In case of Bacillus Overall, the lesion length of plants treated with B1 species, the growth of Xoo was inhibited due to isolate was minimum in comparison with T6, T7 release of antibiotics by bioagents (Antibiosis) and B5 (Table 6). However, enhancement in plant (Lahlali et al., 2013). From in-vitro experiment growth promoting attributes were highest in T6 Table 6: Evaluation of antagonistic activities of selected bioagents against Xoo under glasshouse conditions. 


\begin{tabular}{|l|l|l|l|l|l|l|}
\hline \multirow{2}{*}{ Treatments } & \multicolumn{2}{l|}{ Lesion length (cm) } & \multicolumn{2}{l|}{ Per cent diseased leaf area } & \multicolumn{2}{l|}{ Disease scoring } \\
\cline { 2 - 7 } & $14^{\text {th }} \mathrm{DAI}$ & $21^{\text {st }} \mathrm{DAI}$ & $14^{\text {th }} \mathrm{DAI}$ & $21^{\text {st }} \mathrm{DAI}$ & $14^{\text {th }} \mathrm{DAI}$ & $21^{\text {st }} \mathrm{DAI}$ \\
\hline T6+Xoo & $2.23 \pm 0.31^{\mathrm{b}}$ & $5.60 \pm 0.46^{\mathrm{bc}}$ & 1.06 & 11.63 & 3 & 5 \\
\hline $\mathrm{T} 7+$ Xoo & $2.87 \pm 0.15^{\mathrm{c}}$ & $6.37 \pm 0.61^{\mathrm{c}}$ & 1.30 & 15.87 & 3 & 5 \\
\hline $\mathrm{B} 1+$ Xoo & $2.13 \pm 0.15^{\mathrm{b}}$ & $4.90 \pm 0.26^{\mathrm{b}}$ & 0.94 & 7.82 & 2 & 4 \\
\hline $\mathrm{B} 5+$ Xoo & $2.37 \pm 0.25^{\mathrm{bc}}$ & $6.17 \pm 0.47^{\mathrm{c}}$ & 1.12 & 13.97 & 3 & 5 \\
\hline PC & $4.83 \pm 0.31^{\mathrm{d}}$ & $11.73 \pm 0.50^{\mathrm{d}}$ & 1.58 & 35.86 & 4 & 7 \\
\hline HC & $0.57 \pm 0.55^{\mathrm{a}}$ & $2.17 \pm 0.21^{\mathrm{a}}$ & 0.65 & 2.03 & 2 & 3 \\
\hline
\end{tabular}

Note: Data depicts the mean of four replications. Numerical values with different letters are significantly different $(\mathbf{P}<0.05$, DMRT, SPSS)

Table 7: Macroscopic and microscopic features of potential Trichoderma and Bacillus isolates along with Xoo

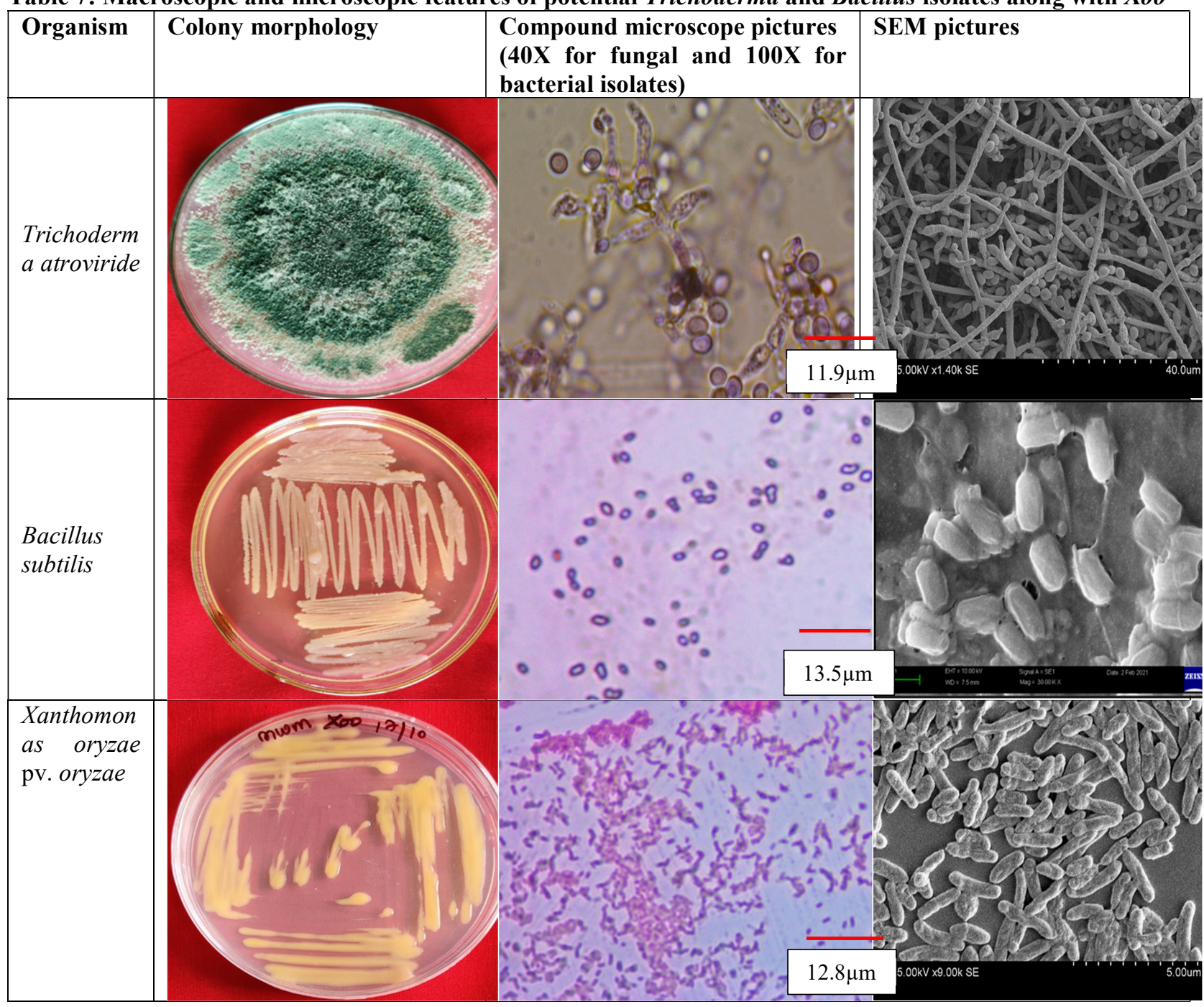

followed by B1, T7 and B5 (Figure 4). The resistance (ISR) when there is occurrence of introduction of bioagents as seed or seedling or soil pathogen (Mukherjee et al., 2013). ISR helps in treatment increase the population of these microbes preconditioning of plant defenses by prior infection in soil and hence results in induced systemic or treatment that results in resistance against 
subsequent challenge by a pathogen (Choudhary et al., 2007). The detailed size, morphology and surface of whole organism viz., T6 (Trichoderma atroviride), B1 (Bacillus subtilis) and Xanthomonas oryzae pv. oryzae were analysed with the help of scanning electron microscopy at various magnifications (Table 7). The conidia of Trichoderma atroviride was smooth, round with size range from $2.5-3.9 \mu \mathrm{m}$ and the conidiophore was branched bearing bottle shaped phialides. The bacterium Bacillus subtilis was rod shaped, atrichous with a size of $1.45 \times 0.62 \mu \mathrm{m}$ and $\mathrm{XoO}$ appeared as rod shaped with size of $1.2 \times 0.52 \mu \mathrm{m}$. Based on results obtained from in-vitro and in-vivo studies isolate $\mathrm{T} 6$ and $\mathrm{B} 1$ were further proceeded for molecular identification. DNA of Trichoderma isolate T6 was amplified using ITS primers and Bacillus isolate B1 using universal primers specific to conserved 16S rRNA region and endoglucanase region (Figure 5). The amplified product was sequenced and obtained results were aligned against NCBI database. These sequences were compared with NCBI database and the percent similarity coefficient of T6 was $99 \%$ identical to Trichoderma atroviride and B1 was 97\% identical to Bacillus subtilis. On the basis of percent similarity coefficient, 20 closest species of T6 and B1 database were analysed and phylogenetic tree was constructed to reconfirm the identity of bioagents. It was found that $\mathrm{T} 6$ was closely related to T. atroviride species and $\mathrm{B} 1$ to Bacillus subtilis (Figure $6 \mathrm{~A}$ and $\mathrm{B}$ ). The culture sequence was submitted to NCBI (Figure $6 \mathrm{C}$ ). NCBI database percent similarity and phylogenetic tree analysis help us to know about the organism at species level. Phylogenetic tree construction helps to enrich our knowledge and understanding in finding out about which species the organism is related to (Soltis and Soltis, 2003). Comparisons of gene sequences of fungal and bacterial bioagents with the closest species database available at NCBI in a phylogenetic context has provided the most meaningful insights in identification and biology of these microbes.

Figure 5: Molecular Identification of selected native isolates Bacillus 1, Trichoderma 6 and Xoo using specific primers

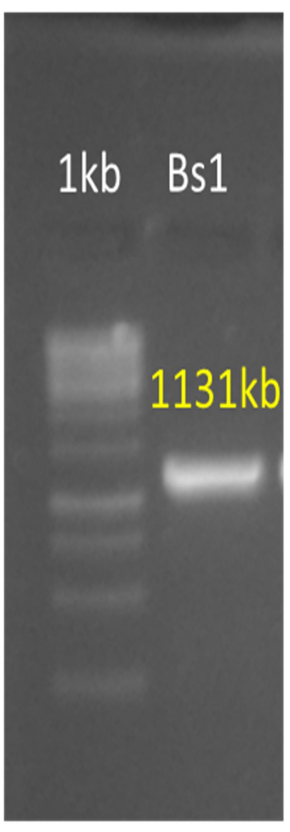

Endoglucanase

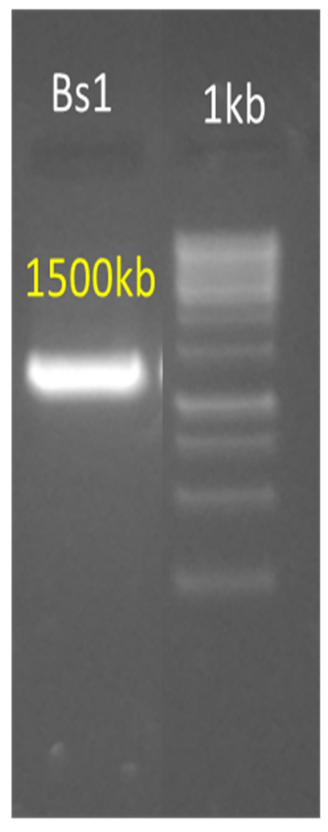

16srRNA

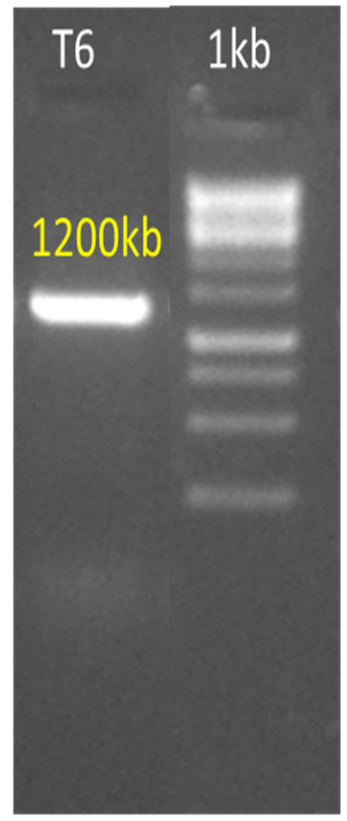

ITS Primer

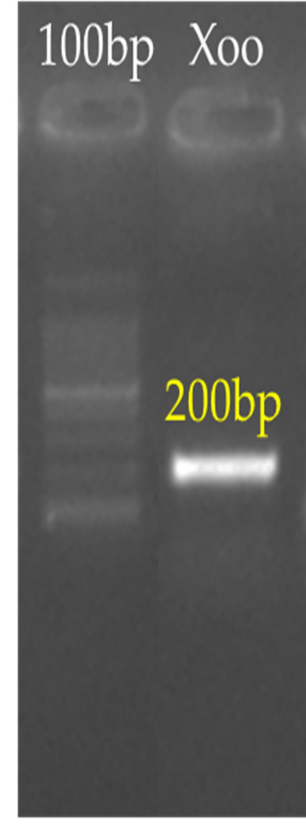

16srRNA 
Figure 6: Identification of selected bioagents

A) Phylogenetic tree of T6 with 20 closest species (NCBI database)

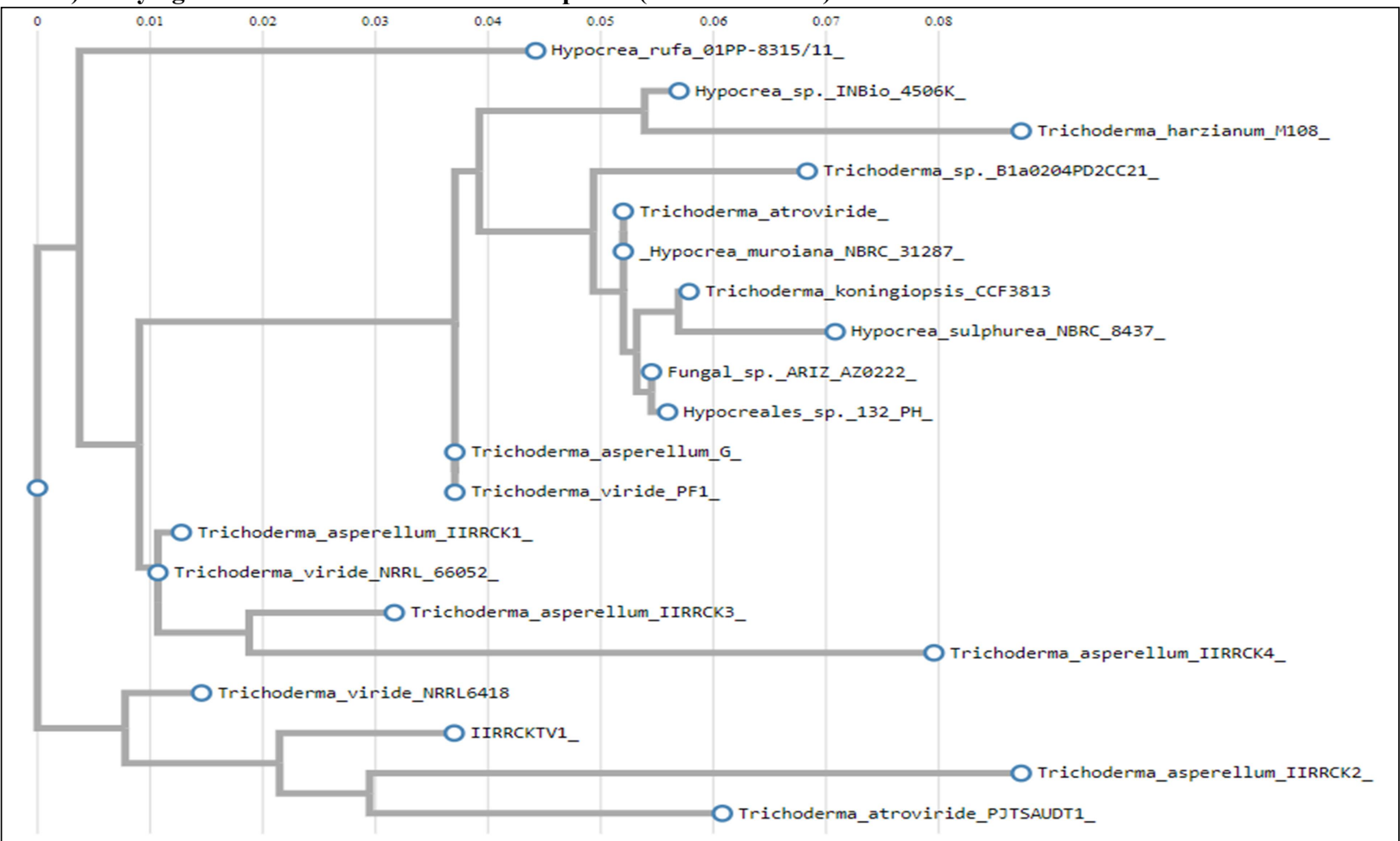

B) Phylogenetic tree of B1 with 20 closest species (NCBI database)

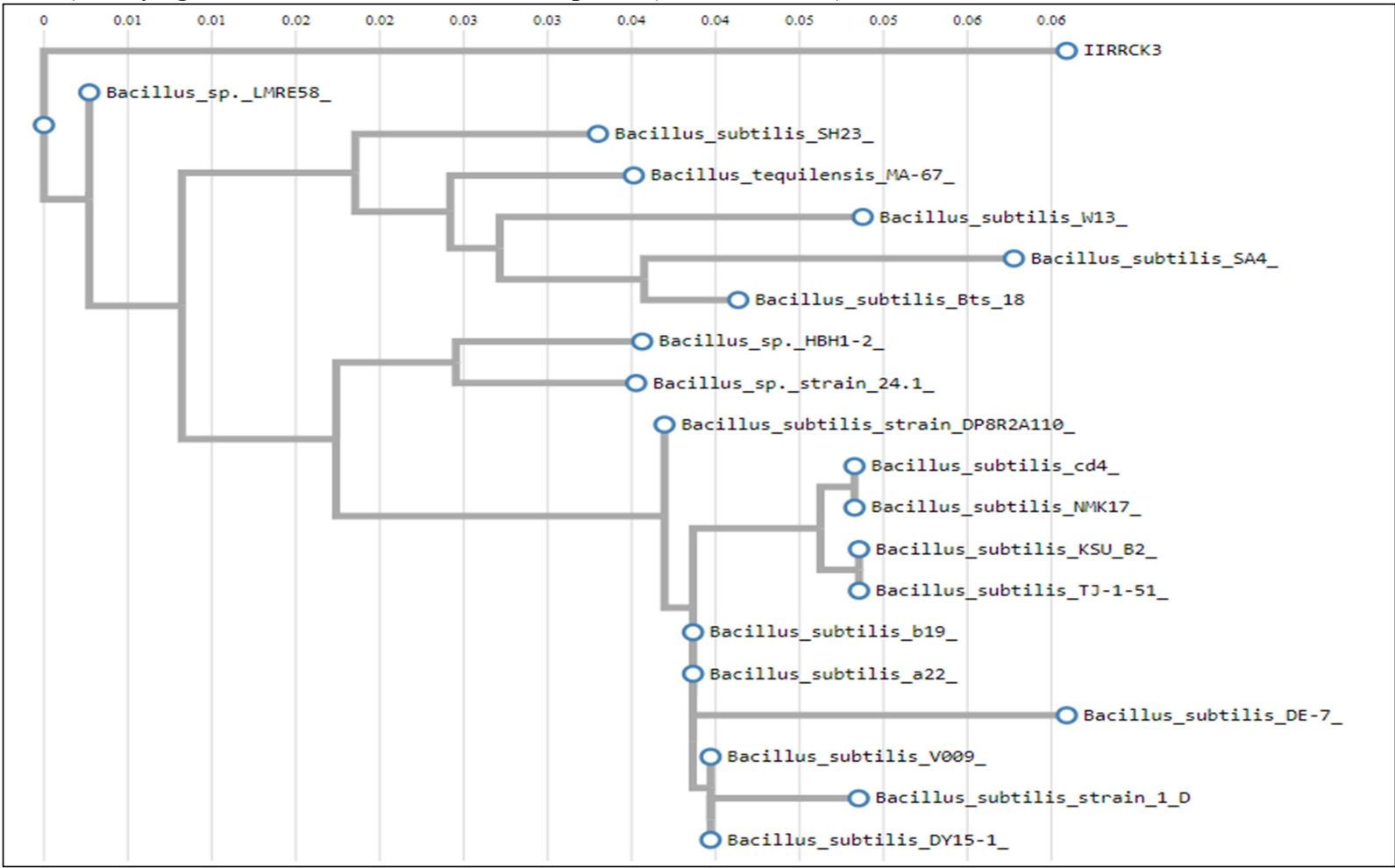


C) Details of bioagents submitted to NCBI

\begin{tabular}{|l|l|l|l|l|}
\hline $\begin{array}{l}\text { Isolate } \\
\text { code }\end{array}$ & Scientific name & $\begin{array}{l}\text { NCBI accession } \\
\text { number }\end{array}$ & Host & Collection date \\
\hline T6 & Trichoderma atroviride & MW188552 & Rice rhizosphere soil & $2019-08-23$ \\
\hline B1 & Bacillus subtilis & MT804606 & Rice rhizosphere soil & $2019-09-15$ \\
\hline
\end{tabular}

\section{Conclusion}

In the present study, two bioagents that induces rice plant growth and suppress its pathogen have been isolated and characterized. The application of bioagents on rice plants inoculated with Xoo has shown effective and successful reduction of the disease. The diverse soil distribution and rice cultivation in Telangana state have given an open chance to isolate beneficial microbes from rice rhizosphere soil, characterised their essential properties and utilize them accordingly against pathogens of rice. Molecular characterisation and

\section{References}

Ashwini, N., \& Srividya, S. (2014). Potentiality of Bacillus subtilis as biocontrol agent for management of anthracnose disease of chilli caused by Colletotrichum gloeosporioides OGC1. 3 Biotech, 4(2), 127-36.

Balouiri, M., Sadiki, M., \& Ibnsouda, S.K. (2016). Methods for in vitro evaluating antimicrobial activity: A review. Journal of Pharmaceutical Analysis, 6(2),71-9.

Bozzola, J.J., \& Russell, L.D. (1999). Electron microscopy: principles and techniques for biologists. Jones \& Bartlett Learning.

Brick, J.M., Bostock, R.M., \& Silverstone, S.E. (1991). Rapid in situ assay for indole acetic acid production by bacteria immobilized on nitrocellulose membrane. Appl Environ Microbial, 57, 535-538.

Brunner, K., Zeilinger, S., Ciliento, R., Woo, S.L., Lorito, M., Kubicek, C.P., \& Mach, R.L. (2005). Improvement of the fungal biocontrol agent Trichoderma atroviride to enhance both antagonism and induction of plant systemic disease resistance. Applied and environmental microbiology, 71(7), 3959-65.

Chinnaswami, K., Mishra, D., Miriyala, A., Vellaichamy, P., Kurubar, B., Gompa, J., Madamsetty, S.P and Raman, M.S. (2021) Native isolates of Trichoderma as bio-suppressants against sheath blight and stem rot pathogens of rice. Egypt Journal Biological Pest Control, 31(1):1-10.

Choudhary, D.K., Prakash, A., and Johri, B.N. (2007). Induced systemic resistance (ISR) in plants: mechanism of action. Indian Journal of Microbiology, 47(4), 289-97. phylogenetic analysis have helped to identify the organism up to species level. Work is in progress to develop an effective formulation for the controlled and safe release of the bioagents in the field conditions and can be used for the management of Xoo.

\section{Acknowledgement}

The authors acknowledge ICAR-Indian Institute of Rice Research and Professor Jayashankar Telangana State Agricultural University for support in the research work conducted.

Coninck, E., Scauflaire, J., Gollier, M., Liénard, C., Foucart, G., Manssens, G., Munaut, F., \& Legrève, A. (2020). Trichoderma atroviride as a promising biocontrol agent in seed coating for reducing Fusarium damping-off on maize. Journal of applied microbiology, 129(3), 637-51.

Doni, F., Isahak, A., Zain, C.R., \&Yusoff, W.M. (2014). Physiological and growth response of rice plants (Oryza sativa L.) to Trichoderma spp. inoculants. Amb Express, $4(1), 1-7$

Gangwar, G.P. \& Sinha, A.P. (2010). Comparative antagonistic potential of Trichoderma spp. against Xanthomonas oryzae pv. oryzae. Annals of Plant Protection Sciences, 18(2), 458-463.

Gravel, V. Antoun, H. \& Tweddell, R.J. (2007). Growth stimulation and fruit yield improvement of greenhouse tomato plants by inoculation with Pseudomonas putida or Trichoderma atroviride: Possible role of indole acetic acid (IAA). Soil Biol. Biochem, 39, 1968-1977.

Gupta, V.G., Schmoll, M., Herrera-Estrella, A., Upadhyay, R.S., Druzhinina, I., \& Tuohy, M. (2014). Biotechnology and biology of Trichoderma. Newnes.

Hastuti, R.D., Lestari, Y., Suwanto, A., \& Saraswati, R. (2012). Endophytic Streptomyces spp. as biocontrol agents of rice bacterial leaf blight pathogen (Xanthomonas oryzae pv. oryzae). HAYATI Journal of Biosciences, 19(4), 155-62.

Istock, Conrad, A. (2008). "Bacillus: Cellular and Molecular Biology." 117-117. 
Kumar, S., \& Singh, A. (2015). Biopesticides: present status and the future prospects. J Fertil Pestic, 6(2), 100-29.

Lahlali, R., Peng, G., Gossen, B.D., McGregor, L., Yu, F.Q., Hynes, R.K., Hwang, S.F., McDonald, M.R., \& Boyetchko, S.M. (2013). Evidence that the biofungicide Serenade (Bacillus subtilis) suppresses clubroot on canola via antibiosis and induced host resistance. Phytopathology, 103(3), 245-54.

Lieckfeldt, E., Samuels, G.J., Nirenberg, H.I., \& Petrini, O. (1999). A morphological and molecular perspective of Trichoderma viride: is it one or two species?. Applied and Environmental Microbiology, 65(6), 2418-28.

Mahesh, C., Malavath, R.N., Balaguruvaiah, D., \& Vidyasagar, G.E. (2018). Genesis, classification and evaluation of some sugarcane growing black soils in semi-arid tropical region of Telangana. Journal of Pharmacognosy and Phytochemistry, 7(3):81-92.

Marin, V.R., Ferrarezi, J.H., Vieira, G., \& Sass, D.C. (2019). Recent advances in the biocontrol of Xanthomonas spp. World Journal of Microbiology and Biotechnology, 35(5), $1-1$.

Miller, G.L. (1959). Use of dinitro salicylic acid reagent for determination of reducing sugar. Anal. Biochem, 31, 426428 .

Mukherjee, P.K., Horwitz, B.A., Singh, U.S., Mukherjee, M., \& Schmoll, M. (2013). Trichoderma in agriculture, industry and medicine: an overview. Trichoderma biology and applications. Boston: CAB International, 16, 1-9.

Naziya, B., Murali, M., \& Amruthesh, K.N. (2020). Plant growth-promoting fungi (PGPF) instigate plant growth and induce disease resistance in Capsicum annuum L. upon infection with Colletotrichum capsici (Syd.) Butler \& Bisby. Biomolecules, 10(1), 41.

Nautiyal, C.S. (1999). An efficient microbiological growth medium for screening phosphate solubilizing microorganisms. FEMS Microbiol. Lett, 170, 265-270.

O'Brien, P.A. (2017). Biological control of plant diseases. Australasian Plant Pathology, 46(4), 293-304.

Payne, S.M. (1994). Detection, isolation, and characterization of siderophores. Methods Enzymol. 235, 329-344.

Pieterse, C.M, Zamioudis, C., Berendsen, R.L., Weller, D.M., Van Wees, S.C., \& Bakker, P.A. (2014). Induced systemic resistance by beneficial microbes. Annual review of phytopathology, 52, 1-12.

Prakash, J., \& Arora, N.K. (2019). Phosphate-solubilizing Bacillus sp. enhances growth, phosphorus uptake and oil yield of Mentha arvensis L. 3 Biotech, 9(4):1-9.

Ram, R.M., Keswani, C., Bisen, K., Tripathi, R., Singh, S.P., \& Singh, H.B. (2018). Biocontrol technology: eco-friendly approaches for sustainable agriculture. InOmics technologies and bio-engineering (pp. 177-190). Academic Press.

Ramada, M.H., Lopes, F.Á., Ulhoa, C.J., \& do Nascimento Silva, R. (2010). Optimized microplate $\beta$-1, 3-glucanase assay system for Trichoderma spp. screening. Journal of Microbiological Methods, 81(1), 6-10.

Reithner, B., Ibarra-Laclette, E., Mach, R.L., \& HerreraEstrella, A. (2011). Identification of mycoparasitismrelated genes in Trichoderma atroviride. Applied and environmental microbiology, 77(13), 4361-70.

Saravanakumar, K., Arasu, V.S., \& Kathiresan, K. (2013). Effect of Trichoderma on soil phosphate solubilization and growth improvement of Avicennia marina. Aquat. Bot, 104, $101-105$

Scavino, A.F., \& Pedraza, R.O. (2013). The role of siderophores in plant growth-promoting bacteria. In Bacteria in agrobiology: crop productivity (pp. 265-285). Springer, Berlin, Heidelberg.

Schwyn, B., \& Neilands, J.B. (1987). Universal chemical assay for the detection and determination of siderophores. Analytical Biochemistry, 160(2), 47-56.

Singh, B.N., Dwivedi, P., Sarma, B.K., \& Singh, H.B. (2019). Trichoderma asperellum T42 induces local defense against Xanthomonas oryzae pv. oryzae under nitrate and ammonium nutrients in tobacco. RSC Advances, 9(68), 39793-810.

Soltis, D.E., \& Soltis, P.S. (2003). The role of phylogenetics in comparative genetics. Plant Physiology, 132(4), 1790-800.

Yousef, C.F., Travieso, M.L., Espinosa, U.M. (2008). Different, overlapping mechanisms for colonization of abiotic and plant surfaces by Pseudomonas putida. FEMS Microbiol. Lett, 288, 118-12. 